\title{
An Affirmative Action Audit for Affirmative Change: A Management Perspective
}

\section{S W Theron and M R Viljoen}

Department of Human Resources Management, University of Pretoria

\section{ABSTRACT}

This paper focuses on management's perception of affirmative action for affirmative change. A questionnaire, developed to measure attitudes towards the implementation of an affirmative action programme, was distributed to managers at all levels of management in a parastatal. Results supply evidence of a negative orientation towards affirmative action amongst younger managers. They hold the view that members of disadvantaged groups are favoured at their expense. Younger managers also perceive older managers not to have the necessary vision and skills to implement an affirmative action programme successfully. It is recommended that line management encourage communication between the different race groups, and develop positive attitudes and expectations towards the employers, the affirmative action programmes and the various jobs available.

JEL J 58

\section{INTRODUCTION}

Transformation is the order of the day. The new political dispensation has set new standards and requirements for organisations in South Africa. Affirmative action, labour legislation, and the Reconstruction and Development Programme (RDP) are some of the large issues at the top of the agenda.

The study on which this paper is based was carried out in a parastatal firm which has to adapt to the South African transformation process. It is serious about affirmative action, participative management, and the RDP (Viljoen, 1997). Human (1993) views affirmative action as temporary intervention designed to achieve equal employment opportunity, without lowering standards and unduly trammelling the career aspirations or expectations of current organisational members competent in their jobs. 
The RDP endorses affirmative action to empower communities and individuals from previously disadvantaged groups in society. The affirmative action programme must include mechanisms to make available resources needed to set up enterprises at a number of levels, training and upgrading, and civic education to ensure that groups and individuals recognise and exercise their rights (ANC, 1994). Affirmative action may raise the blood pressure of an average middleaged white South African, but it is also stressful to black professionals who experience a work environment void of responsibility, doing work at entry level. White colleagues seem to be hostile towards affirmative action appointments, assuming that black people do not have the necessary skills (Roberts, 1997: 1822) ${ }^{1}$. Makoena ${ }^{2}$ as quoted by Roberts, op.cit., is adamant that affirmative action is not about putting incompetent people in positions where they cannot cope and doing competent people out of jobs. It is rather about identifying the people with the necessary ability, and training them for positions where they can be productive.

The main aim of the study was to determine management's perceptions of affirmative action, especially to:

- Determine by means of an affirmative action audit questionnaire, management's attitude towards affirmative action with special reference to the biographical variables age, race, gender, years of service and management level;

- Determine whether there is any resistance to change and the level of leadership skills and abilities amongst management to facilitate the affirmative action programme and related changes; and

- Make recommendations to enable the company implement affirmative action in an acceptable and efficient way.

\section{KEY CONCEPTS OF THE STUDY}

It is necessary to define and explain the following concepts used in this study.

\section{Affirmative Action}

Affirmative action means different things to people of different backgrounds. For some it has a positive connotation; for others it is a frightening concept. Albie Sachs, as quoted by Herbert (1994: 2), embraces most of the feeling towards 
affirmative action in saying "One person's dream of advancement is another person's nightmare."

The Black Management Forum set the following objectives in their Affirmative Action Blueprint (1993):

- Affirmative action must help to reverse the prevailing situation of disadvantage of the majority;

- Affirmative action has to create opportunities for education, training and development in the workplace, and these opportunities have to result in the demonstrable economic empowerment of those intended to benefit from them at all levels; and

- Affirmative action must bring about a complete transformation of the racist and sexist attitudes that have been at the core of organisations in the past. The Black Management Forum (BMF) regards an organisation as the primary beneficiary of affirmative action. Black men and women are seen as the secondary beneficiaries. The term "black people" refers to all individuals who were politically excluded from a meaningful role within South African society for the reason that they were not white. The BMF recognises that black people comprise three population groups, namely African, Indian and Coloured, and empowerment should reflect these groups according to their proportionate demographic representation (BMF, 1993) ${ }^{3}$.

Affirmative action is closely related to equal employment which implies equal access for all people to participation in the empowerment process and advancement on the basis of merit, ability and potential (Luhabe, 1993: 26). The Employment Equity Act (no 97 of 1998) requires organisations/companies to commit themselves to the creation of a diverse workforce broadly representative of all the people in the country. In terms of this Act, all organisations/companies will be required to take steps to eliminate unfair discrimination in their employment policies and practices. Employment equity goes beyond affirmative action. The Employment Equity Act refers to a policy of fairness, the granting of equal access to all people, whereas in terms of affirmative action, organisations have to ensure access for disadvantaged groups. One of the measures that can accelerate the advancement of disadvantaged groups, is affirmative action (Landman, 2000: 187).

Affirmative change has to be tailored according to the needs of a particular organisation. The integrated vision must be one where the individual in the organisation and the organisation itself are inexorably linked, and which redefines the way that an organisation and its members interact with one another in order to create an environment of affirmative change and opportunity for all (Viljoen, 1997). 
As regards the preferential treatment of the disadvantaged groups, the question arises what is the price that an organisation pays for this preferential treatment. Instead of looking at the price, one should rather look at the return on the investment. There are basically two scenarios, namely a low and a high return on investment. The low return scenario occurs when an organisation implements affirmative action incorrectly and/or ineffectively. This usually happens when an organisation views affirmative action as a political imperative that has to be complied with, and not as a business objective which needs to be sustainable within the framework of the organisational objectives as a whole (Bendix, 1996). The revolving-door syndrome of the ineffective implementation of affirmative action occurs when personnel composition has a negative image and management believes that a few black-faces at the right levels will make the organisation appear politically correct (Thomas, 1996: 6).

Low return on investment is embedded in:

- High recruitment costs;

- Too high and unrealistic salaries paid to affirmative action appointees; and

- Dissatisfaction among the current workforce and experience of affirmative action as reverse discrimination.

As regards the high return scenario, the efficient and correct implementation of affirmative action demands the recruitment and selection of persons with known competencies or potential to fill positions worthy of their ability. Previously disadvantaged people should be trained and developed to have greater vertical mobility in future. A continuous monitoring system should be implemented as well as the adoption of demographic spread at all levels of the organisation.

\section{Role of Management}

It is line management who are tasked and held accountable for the implementation of the affirmative action strategy with the human resource department in support (Charlton \& Van Niekerk, 1994: 155). Kemp (quoted by De Witt, 1996: 1) agrees that management are responsible for policy implementation. Without managerial support and commitment to affirmative action, nothing will change. De Witt (1996: 15) is adamant that the success or failure of the implementation of affirmative action lies with management. Given that white males constitute the majority of decision-makers and are people of influence within the organisation, it is self-evident that according to the information processing model of perception, the white male manager will have certain perceptions of the company's affirmative action policy, its implementation, and of anyone who has anything to do with it. These managers will eventually, as Human (1996: 6) puts it, learn to play the game and learn the 
basic vocabulary of non-discriminatory discourse in the absence of any real change of heart. A change in dialogue will not always reflect a change of heart and basic prejudices and insecurities remain. Much of the reluctance of line management to spend time on and take responsibility for affirmative action is due to their not knowing why this is important, how it will benefit themselves in particular, and how to go about this task (Human, 1996).

Organisations view their middle managers as the stabilisers who make enduring changes possible, linking corporate strategy to action. Middle managers are important as agents of change driving the corporate transformation (Dauphinais, 1996: 12-13). Dauphinais, op.cit, describes the role of middle managers by emphasising four important aspects of their accoutrements, namely creators and implementers, influencers, key sources of stability, and workhorses of continuous transformation.

\section{RESEARCH DESIGN AND METHOD}

As the principal aim of this study is to ascertain management's attitudes towards affirmative action, the survey method was appropriate. The design was crosssectional as the survey was conducted at one time only. The formulation of a hypothesis is not considered necessary as this is a survey and not a laboratory experiment.

\section{Measuring Instrument}

A questionnaire compiled by Martins (1995: 3-11) which measures the organisation's attitude to the implementation of an affirmative action programme was chosen. This questionnaire consists of 80 items and measures seven dimensions, namely skills development, relationships and trust, organisational values, affirmative action programmes, company image, management skills and abilities, and policies and procedures. The affirmative action dimension has three subdimensions, namely training and development, promotions and recruitment, and appointments. In the analysis of data these three dimensions will be separately treated. Martins found an overall reliability (Cronbach's Alpha) of 0.938 . Viljoen (1997) obtained a split-half reliability coefficient (equal length) with Spearman Brown correction of 0.92 . Respondents have to respond on a five point Likert scale ranging from 1 (differ strongly) to 5 (agree strongly). 


\section{Data Collection}

No sampling was done and the questionnaire was distributed to all individuals within the four levels of management, namely top, senior, middle, and junior management. These levels include members of both gender and all race (cultural) groups. A total of 424 questionnaires were distributed of which 182 were returned, resulting in a response rate of 42.9 per cent.

\section{Data Processing}

Data were analysed by means of descriptive and inferential statistics, namely one-way analysis of variance, available on the SPSS ${ }^{R}$ package.

\section{RESULTS}

The mean score fluctuates between 2.37 and 4.5 which indicates that responses vary between differ on the statement to strongly agree with it. The standard error of the mean is generally large which implies that the results of the study cannot be generalised to the total population. Also, the distribution is skewed ${ }^{4}$.

A one-way analysis of variances was done with years of service, age, company divisions and management levels as the independent variables ${ }^{5}$. The results are presented in tables 1 to 4 . Results of the one-way analysis of variance with regard to years of service are shown in Table 1.

Table 1 One-way analysis of variance - years of service

\begin{tabular}{|c|l|c|c|}
\hline \multicolumn{1}{|c|}{ Variable } & \multicolumn{1}{|c|}{ Dimension } & F-ratio & $\begin{array}{c}\text { Probability } \\
\text { (p) }\end{array}$ \\
\hline \multirow{5}{*}{ Years of service } & Organisational values & 0.6421 & 0.5274 \\
\cline { 2 - 4 } & Training and development & 0.6023 & 0.5487 \\
\cline { 2 - 4 } & Promotions & 4.3203 & $0.0148^{*}$ \\
\cline { 2 - 4 } & Recruitment and appointments & 2.9333 & 0.0558 \\
\hline & Company image & 1.8314 & 0.1633 \\
\hline & Trust & 1.0669 & 0.3464 \\
\cline { 2 - 4 } & Skills development & 0.9868 & 0.3749 \\
\cline { 2 - 4 } & Management skills & 1.5783 & 0.2093 \\
\hline & Policies and procedures & 2.0420 & 0.1329 \\
\hline & Affirmative action programmes & 1.0005 & 0.3699 \\
\hline
\end{tabular}

$\left({ }^{*} \mathrm{p} \leq 0.05\right)$ 
The category "years of service" was divided into four levels, namely employees with less than four years of service, 4 to 10 years, 11 to 15 years, and more than 15 years of service. Table 1 shows that years of service has only one significant effect ( $p \leq 0.05$ ), namely with regard to the dimension of promotions. Post hoc comparisons by means of the Scheffe test showed that employees with service of less than four years differ significantly from employees in the ranges of four to 15 years. Workers in the category of less than four years of service have a more positive view of the process of promotions than respondents in the categories four years of service to 15 years and more.

Results of the one-way analysis of variance with age as the independent variable are shown in Table 2.

Table 2 One-way analysis of variance - age

\begin{tabular}{|l|l|c|c|}
\hline Variable & \multicolumn{1}{|c|}{ Dimension } & F-ratio & $\begin{array}{c}\text { Probability } \\
(\mathbf{p})\end{array}$ \\
\hline \multirow{4}{*}{ Age } & Organisational values & 2.3752 & 0.0960 \\
\cline { 2 - 4 } & Training and development & 3.1924 & $0.0435^{*}$ \\
\cline { 2 - 4 } & Promotions & 3.8990 & $0.0211^{*}$ \\
\cline { 2 - 4 } & Recruitment and appointments & 9.5165 & $0.0001^{*}$ \\
\cline { 2 - 4 } & Company image & 4.8734 & $0.0087^{*}$ \\
\cline { 2 - 4 } & Trust & 3.3625 & $0.0370^{*}$ \\
\cline { 2 - 4 } & Skills development & 3.5799 & $0.0299^{*}$ \\
\cline { 2 - 4 } & Management skills & 7.5889 & $0.0007^{*}$ \\
\cline { 2 - 4 } & Policies and procedures & 5.2937 & $0.0059^{*}$ \\
\cline { 2 - 4 } & Affirmative action programmes & 5.3011 & $0.0059^{*}$ \\
\hline
\end{tabular}

$\left({ }^{*} \mathrm{p} \leq 0.05\right)$

The category "age" was divided into three levels, namely 35 years and younger, 36 to 45 years, and 46 years and older. Table 2 shows that age has an overall significant effect $(p \leq 0.05)$ on all the dimensions except organisational values. Post hoc comparisons by means of the Scheffe test showed that the three age groups differ significantly with regard to all the abovementioned dimensions except promotions, trust, and skills development.

Employees in the age group 35 years and younger take the view that there is no comprehensive and effective training at all levels and for all groups, enabling people to have training for their current jobs and also their future positions. The age group 46 years and older felt more positive in this regard. The age group 35 years and younger differs significantly from both the other two age groups on recruitment and appointments, with the groups 36 to 45 years and 46 years and 
older holding a more positive view than the age group 35 years and younger. As regards company image, the age group 35 years and younger has a more negative view than the group 36 to 45 years of age. As regards management skills, the age groups 36 to 45 years and 46 and older viewed management as having the necessary skills and vision to lead the company successfully. Subjects in the age group 35 years and younger did not view management in the same positive light.

As regards policies and procedures, age group 35 years and younger perceive the company not to apply policies and procedure equally to the different race and gender groups. The age group 35 years and younger differs significantly from the age group 46 years and older on affirmative action programmes. The younger group was more negatively inclined while the older group was satisfied with affirmative action programmes.

Results of the one-way analysis of variance with company division as independent variable are presented in Table 3.

Table 3 One-way analysis of variance - company division

\begin{tabular}{|c|l|c|c|}
\hline Variable & \multicolumn{1}{|c|}{ Dimension } & F-ratio & $\begin{array}{c}\text { Probability } \\
\text { (p) }\end{array}$ \\
\hline \multirow{5}{*}{ Division } & Organisational values & 0.2104 & 0.8105 \\
\cline { 2 - 4 } & Training and development & 1.8487 & 0.1606 \\
\cline { 2 - 4 } & Promotions & 0.6227 & 0.5377 \\
\cline { 2 - 4 } & Recruitment and appointments & 2.8294 & 0.0617 \\
\cline { 2 - 4 } & Company image & 0.9467 & 0.3900 \\
\cline { 2 - 4 } & Trust & 1.4557 & 0.2362 \\
\cline { 2 - 4 } & Skills development & 0.8962 & 0.4100 \\
\cline { 2 - 4 } & Management skills & 2.5025 & 0.0848 \\
\cline { 2 - 4 } & Policies and procedures & 0.5344 & 0.5870 \\
\cline { 2 - 4 } & Affirmative action programmes & 1.1404 & 0.3223 \\
\hline
\end{tabular}

$\left({ }^{*} p \leq 0.05\right)$

It is clear from Table 3 that the independent variable, company division, has no significant effect $(p>0.05)$ on any of the dimensions of the affirmative action audit questionnaire.

The results of the one-way analysis of variance with management level as the independent variable are shown in Table 4. 
Table 4 One-way analysis of variance - management levels

\begin{tabular}{|c|l|c|c|}
\hline \multirow{1}{*}{ Variable } & \multicolumn{1}{|c|}{ Dimension } & F-ratio & $\begin{array}{c}\text { Probability } \\
\text { (p) }\end{array}$ \\
\hline \multirow{4}{*}{$\begin{array}{l}\text { Management } \\
\text { level }\end{array}$} & Organisational values & 3.8698 & $0.0227^{*}$ \\
\cline { 2 - 4 } & Training and development & 1.0534 & 0.3510 \\
\cline { 2 - 4 } & Promotions & 0.4423 & 0.6433 \\
\cline { 2 - 4 } & Recruitment and appointments & 1.2698 & 0.2834 \\
\cline { 2 - 4 } & Company image & 2.6619 & 0.0726 \\
\cline { 2 - 4 } & Trust & 0.8807 & 0.4164 \\
\cline { 2 - 4 } & Skills development & 2.1662 & 0.1177 \\
\hline & Management skills & 2.8360 & 0.0614 \\
\cline { 2 - 4 } & Policies and procedures & 3.2595 & $0.0407^{*}$ \\
\cline { 2 - 4 } & Affirmative action programmes & 0.5505 & 0.5777 \\
\hline
\end{tabular}

$\left({ }^{*} \mathrm{p} \leq 0.05\right)$

It is quite evident from Table 4 that the three management levels, top, middle, and junior management, differ significantly $(p \leq 0.05)$ on only two dimensions, namely organisational values and policies and procedures. Post hoc comparisons by means of the Scheffe test showed that top management differ significantly on organisational values from middle management. Top management view all the employees in the company as having consensus on organisational values. Middle management, on the other hand, do not share this positive view by top management. Top and middle management differ significantly on policies and procedures. Middle management do not perceive the company as equal in the application of policies and procedures with regard to the different race groups. The human resources policies are also not progressive enough. Top management feel comfortable with the equity of policies and procedures.

\section{CONCLUSIONS AND RECOMMENDATIONS}

\section{Age}

It is quite conspicuous that managers in the younger age group (35 years and younger) are negatively inclined to the affirmative action programme. They viewed training and development as insufficient and not satisfying their needs of comprehensive training for their current jobs and possible future positions. This may be due to the younger group perceiving their jobs to be precarious and a need to be fit for other positions in future, should the eventuality arise. This group was also negatively inclined towards the company's application of its 
policies and procedures and affirmative action programmes. The two older groups ( 36 to 45 and 46 years and older) express satisfaction with affirmative action. Again the inference can be made that younger employees felt insecure and therefore hostile to affirmative action. They may also view the application of policies and procedures as discrimination against them.

\section{Years of Service}

As regards years of service, it is again noticeable that employees with less than four years of service differ significantly from employees with four or more years of service, the former revealing a more positive view of the process of promotions.

\section{Company Division}

The independent variable, company division, had no effect on the dependent variables, thus revealing a uniformity of attitude towards affirmative action.

\section{Management Level}

As regards management level, top managers are quite comfortable with the application of the affirmative action programme. They are of the opinion that there is consensus among employees on organisational values. They are also quite comfortable with the equity of policies and procedures. Middle management felt just the other way round.

Special attention should be given to the white male and his inclusion in an organisation's workforce with regard to its affirmative action policy. White males, and especially the younger ones, feel that upward mobility is a function of race and not the result of merit and proven competence. They fear unequal treatment in the selection process. It is self-evident that the white male will jump to negative conclusions concerning the affirmative action policy of the company, the implementation thereof, and anyone who has anything to do with it. Negative perceptions must however not be allowed to develop.

The organisation must affirm equal opportunities for white males by ensuring that they are not discriminated against, and see to it that their right to equal opportunity is entrenched in the organisation's policies and procedures. The organisation should also involve the workforce in the design and implementation of the affirmative action programme. Consideration should be given to the conducting of workshops to educate and train employees conceming the achievement of equity for the different groups. During workshops the affirmative action policies and programmes should be clearly communicated to 
the employees. The exchange of views between workers and management is of great importance. White males should also be sensitised to changing opportunities and demands in the job market, and change their perceptions accordingly. Organisations should address this issue in introductory programmes and/or when recruiting potential employees (Viljoen, 1997; Fischer, 1996: 30-34; Norris, 1996: 35-39).

As line management is in close contact with the workers, the implementation of affirmative action in the various departments is their responsibility. It is recommended that line management encourage communication between the different race groups and develop positive attitudes and expectations towards the employer, the affirmative action programme, and the various jobs available.

In summary, the survey highlights that members of previously disadvantaged groups should not be appointed for the sake of getting the numbers right. Implementing affirmative action as window dressing rather than finding the skills and abilities necessary to do the job can be a costly option in the long run.

\section{ENDNOTES}

1 Roberts compiled the views on affirmative action of black professionals and South Africa's top business leaders.

2 Maja Mokoena is on the highest level of management (one level below a directorship) with a large merchant bank.

3 -The BMF also recognises the existence of other forms of discrimination such as handicapped and gay people.

4 It is not considered necessary to present a table of descriptive statistics.

5 In each case a significance level of $\mathrm{p} \geq 0.05$ was found for the tests of homogeneity of variance (Cochran's C; Bartlett-Box F, and Maximum Variance/Minimum Variance) indicating an equity of variance and therefore safe to use the one-way analysis of variance.

\section{REFERENCES}

1 AFRICAN NATIONAL CONGRESS (ANC) (1994) The Reconstruction and Development Programme, Johannesburg, Umanyano Publishers.

2 BENDIX, S. (1996) Industrial Relations in South Africa, Kenwyn: Juta and $\mathrm{Co}$, Ltd.

3 BLACK MANAGEMENT FORUM (BMF) (1993) Affirmative Action Blueprint, Johannesburg, BMF Policy Statement. 
4 CHARLTON, G.D. AND VAN NIEKERK, N. (1994) Affirmative Action - Beyond 1994, Kenwyn, Juta and Co., Ltd.

5 DE WITT, D.E. (1996) "The Views of Management on Affirmative Action in TELKOM SA Ltd", University of South Africa, Pretoria, Unpublished MBA dissertation.

6 DAUPHINAIS, G.W. (1996) "Who's Minding the Middle Manager", HR Focus.

7 EMPLOYMENT EQUITY ACT, ACT 97 of 1998, Govemment Printers, Pretoria.

8 FISCHER, S. (1996) "Affirming Equal Opportunity for White Males", People Dynamics, 14(3).

9 HERBERT, T. (1994) Affirmative Action in the South African Workplace: Allowing Black Eagles to Soar, Cape Town, Trevor Herbert.

10 HUMAN, L. (1993) A Practical Guide to Affirmative Action and the Development of People, Kenwyn, Juta and Co., Ltd.

11 HUMAN, L. (1996) "Diversity During Transformation", Human Resource Management Joumal, 12(2).

12 LANDMAN, C.G. (2000) "A Phenomenological Analysis of a Career Planning System within an Organisation with a Delayered Organisational Structure", University of Pretoria, Pretoria, Unpublished Doctoral Thesis.

13 LUHABE, W. (1993) "Affirmative action: Creating the Reality", People Dynamics, $11(8)$.

14 MARTINS, N. (1995) "Affirmative Action: A Consensus Approach in Analysing Employee's Perceptions", Management Dynamics, 12(7).

15 NORRIS, B. (1996) "Manage Diversity or Sink", People Dynamics, 14(6).

16 ROBERTS, A. (1997) "Affirmative Action: Hell for Blacks too?" Financial Mail, 144(2).

17 THOMAS, D. (1996) Beyond Affirmative Action. Managing Diversity for Competitive Advantage in South Africa, Randburg, Knowledge Resources.

18 VILJOEN, M.R. (1997) "An Affirmative Action Audit for Affirmative Change - A Management Perspective", University of Pretoria, Pretoria, Unpublished Master's Dissertation. 